\title{
ANALISIS NILAI-NILAI MULTIKULTURAL DALAM BUKU TEKS SISWA MATA PELAJARAN PENDIDIKAN AGAMA ISLAM (PAI) KELAS VII SMP
}

\author{
Aisyah Dana Luwihta \\ Fakultas : Tarbiyah/PAI STAI Hasan Jufri Bawean \\ aisyahdanaluwihta@gmail.com
}

\begin{abstract}
Abstrak
Indonesia adalah salah satu Negara yang dilihat dari aspek sosiokultur dan geografis begitu beragam seperti Islam, Katolik, Kristen Protestan, Hindu, Budha, Konghucu serta berbagai aliran kepercayaan. Keragaman apabila tidak disadari bisa menjadi pemicu konflik dan kekerasan yang dapat menggoyahkan sendi-sendi kehidupan berbangsa dan bernegara apabila tidak dikelola dengan tepat dan baik. Penelitian ini bertujuan untuk menganalisis dan mendiskripsikan nilai-nilai multikultural yang dikembangkan dalam buku teks siswa mata pelajaran PAI kelas VII SMP dan ketepatan nlai-nilai multkultural dengan komponen buku. Metode Penelitian ini menggunakan pendekatan kualitatif dengan jenis penelitian yang bersifat kepustakaan (Library Research) dengan menelaah dokumen yaitu buku teks siswa PAI dan Budi Pekerti kelas VII SMP. Teknik analisis data meliputi analisis isi (content analyssi) dan analisis kritis. Hasil penelitian menunjukkan bahwa: (1) muatan nilai-nilai multikultural yang dikembangkan didalam buku teks PAI dan Budi Pekerti kelas VII SMP mencakup 4 nilai yaitu 1) Nilai Tooleransi, 2) Nilai Demokrasi, 3) Nilai Kesetaraan/kesamaan, 4) Nilai keadilan. (2) Ketepatan dalam mengembangkan nilai-nilai multikultural pada komponen buku teks siswa mata pelajaran pendidikan agama Islam (PAI) untuk kelas VII SMP dikatakan kurang tepat. Nilai-nilai multikultural secara keseluruhan hanya mencapai $21 \%$.
\end{abstract}

Kata kunci: Nilai-nilai Multikultural, Buku Teks PAI dan Budi Pekerti

\section{A. PENDAHULUAN}

Buku teks atau buku pelajaran sebagai salah satu sarana penunjang pembelajaran yang tergolongkan pada bahan ajar cetak memeliki karakterisitik tersendiri yang disesuaikan dengan kurikulum yang diberlakukan dalam hal isi atau konten buku. Selain itu disisi lain bahwa dalam pebuatan buku pelajaran pemerintah memberikan standar kelayakan melalui Badan Standar Nasional 


\section{Aisyah Dana Luwihta}

Pendidikan (BSNP). ${ }^{1}$

Dalam stuktur kurikulum 2013 yang merupakan jawaban dari ketidakpuasan terhadap KTSP, maka rumusan Kompetensi Inti atau disingkat KI (yang dalam KTSP disebut Standar Kompetensi) di bagi menjadi empat kompetensi, yakni KI 1 sikap spiritual, KI 2 Sikap Sosial, KI 3 Pengetahuan, dan KI 4 Keterampilan. Sehingga dalam pengembangannya Kompetensi dasar hingga evaluasi pun harus bermuatan keempat kompetensi tersebut. ${ }^{2}$

Berawal dari hasil penelitian yang dilakukan oleh tim Center for Religious and Cross-Cultural Studies (CRCS) Pascasarjana UGM mengenai buku panduan yang diterbitkan oleh Buku Sekolah (BSE) yang pada saat penelitian dilakukan hanya buku pendidikan Agama untuk kelas IV, VIII, dan X saja yang telah dicetak dan disebarluaskan. Dalam pembahasannya bahwa dalam penelitain yang dilakukan oleh CRCS merupakan sikap kritis terhadap pendidikan Agama dalam kurikulum 2013 mencakup 3 aspek yaitu: pertama, terlalu besar muatan dogma, kedua, minimnya refleksi dan semangat menghargai perbedaan, ketiga, terbatasnya interaksi antar Agama. ${ }^{3}$

Aspek yang pertama ini dalam buku Pendidikan Agama Islam, jika dibandingkan dengan kurikulum KTSP, kurikulum PAI 2013 banyak memuat materi-materi baru. Khusunya dalam pendidikan agama Islam kelas $\mathrm{X}$, materi

\footnotetext{
${ }^{1}$ Peraturan Pemerintah No. 19/2005 pasal 43

2 Herry Widyastono, Pengembangan Kurikulum di Era Otonomi Daerah, (Jakarta: Bumi Aksara, 2014), Hlm. 145-147

${ }^{3}$ Suhadi, dkk, Politik Pendidikan Agama kurikulum 2013 dan Ruang Publik sekolah, CRCS, Sekolah Pascasarjana, UGM, 2014.Hlm. 33-39
} 


\section{Analisis Nilai-Nilai Multikultural Dalam Buku Teks Siswa Mata Pelajaran Pendidikan Agama Islam (PAI) Kelas VII SMP}

baru tersebut cenderung menonjolkan penegasan indentitas ke-Islaman, seperti: keharusan berpegang teguh kepada Al-Qur'an, Hadits, dan Ijtihad sebagai sumber hukum Islam, mengatur cara berpakaian, serta revitalisasi dakwah. Dari materi yang terdapat dalam kurikulum 2013 tersebut di atas tidak ditemukan dalam KTSP. Dalam kaitannya dengan sumber hukum Islam, Dalam kurikulum 2013 sumber hukum Islam hanya dibatasi pada tiga sumber; Al-Qur'an, hadits, dan Ijtihad ulama terdahulu. Hal ini dapat mengarah kepada reduksi dan pendangkalan kekayaan khazanah ke-Islaman yang bisa terjebak pada eksklusivisme dan kemandegan berfikir. Hal tersebut akan berdampak pada penolakan terhadap adanya interpretasi ulang atas persoalan terdahulu serta upaya reaktualisasi ajaran Islam dalam menjawab problem kekinian. ${ }^{4}$

Apek yang kedua ini bila dicermati lebih lanjut, pada aspek materi Pendidikan Agama Islam dan Budi Pekerti kelas VIII SMP/MTs terdapat kekuragan materi di dalamnya yang diantaranya masih minim refleksi dan semangat menghargai perbedaan. Misalnya dalam buku teks PAI kelas VIII yang menyebutkan "memiliki sikap santun dan menghargai teman, baik dirumah, sekolah, dan di masyaratakat sekitar". PAI masih kurang dalam memberikan porsi untuk mengembangkan sikap inklusif atau keterbukaan. Hal ini bisa jadi tidak selalu didorong oleh semangat eksklusif yang ingin ditransformasikan kepada siswa, tetapi dikarenakan padatnya porsi menghafal ayat suci dan

\footnotetext{
${ }^{4}$ Ibid, hlm, 34-35
} 


\section{Aisyah Dana Luwihta}

memahami praktik ibadah. Situasi ini menjadikan lemahnya refleksi nilai yang terkandung dalam agama Islam itu sendiri.

PAI sangat menekankan aspek penguasaan ajaran dan cenderung meminggirkan aspek refleksi yang seharusnya sangat penting. Dengan jumlah jam pelajaran yang ada, beban menghafal teks ayat suci dan mendalami praktik ibadah yang menyita sangat banyak waktu cenderung menggeser pentingnya mentranformasikan nilai-nilai spiritual kepada siswa. ${ }^{5}$

Aspek yang ketiga ini adalah bahwa materi PAI menitikberatkan pada aspek pembentukan sikap. Dalam PAI kelas IV, misalnya, siswa diharapkan memiliki sikap pantang menyerah sebagai implementasi dari pemahaman kisah Nabi Musa a.s. dan memiliki prilaku mengkonsumsi makanan dan minuman yang halal dan bergizi dalam kehidupan sehari-hari. Namun demikian, hampir semua materi PAI berorientasi ke dalam, dan sangat membatasi diri terhadap orientasi memahami keragaman agama.

Dari tiga aspek yang ditemukan dalam penelitian oleh CRCS di atas menunjukan masih sempitnya ruang untuk pendidikan multikultural dalam buku teks Pendidikan Agama Islam dan Budi Pekerti kelas IV, VIII dan X yang diterbitkan oleh Kemendikbud berdasarkan Kurikulum 2013. Lalu bagaimana dengan buku teks Pendidikan Agama Islam dan Budi Pekerti pada kelas-kelas yang lain yang disusun dan diterbitkan satu tahun setelah ketiga kelas tersebut.

\footnotetext{
${ }^{5}$ Ibid, Hlm, 37
} 


\section{Analisis Nilai-Nilai Multikultural Dalam Buku Teks Siswa Mata Pelajaran \\ Pendidikan Agama Islam (PAI) Kelas VII SMP}

Berangkat dari latar belakang di atas maka penelitian ini akan mencoba menganalisis lebih dalam mengenai muatan-muatan nilai multikultural dalam buku teks Pendidikan Agama Islam dan Budi Pekerti Kurikulum 2013 yang peneliti fokuskan pada buku teks Pendidikan Agama Islam dan Budi Pekerti kelas VII dengan asumsi dasar bahwa berdasarkan hasil penelitian yang dilakukan oleh CRCS bahwa pada buku teks Pendidikan Agama Islam dan Budi Pekerti kelas VIII lebih banyak menekankan pada hafalan ayat-ayat dan praktik ibadah, padahal pendidikan agama di sekolah seharusnya memberikan penekanan pada aspek transfer nilai yang berakar dari agama yang salah satunya adalah nilai multikultural.

\section{B. LANDASAN TEORI}

\section{Pengertian Pendidikan Multikultural}

Menurut definisi James Banks bahwa pendidikan multikultural sebagai pendidikan untuk people of color. ${ }^{6}$ Artinya, pendidikan multikultural ingin mengeksploitasi perbedaan sebagai keniscayaan (anugrah Tuhan/Sunnatullah).

Menurut James A. Banks yang dimaksud dengan pendidikan multikultural mencakup tiga hal, yaitu 1) Pendidikan multikultural sebagai ide atau konsep, 2) sebagai gerakan reformasi pendidikan dan 3) sebagai suatu proses. Sebagai suatu ide atau konsep, pendidikan multikultural ditekankan pada keharusan memberikan kesempatan memperoleh pendidikan yang sama bagi setiap peserta didik tanpa memandang dari kelompok mana dia berasal.

${ }^{6}$ James A. Banks \& Cherry A. McGee, Multicultural Education: Issues and Perspectives (Boston: Allyn and Bacon, 1989), hlm. 3. 


\section{Aisyah Dana Luwihta}

sebagai suatu gerakan reformsi pendidikan, pendidikan multikultural mencoba untuk merubah kurikulum dan paradigma sekolah maupun institusi pendidikan sehingga tercipta pendidikan yang tidak diskriminatif, yang toleran, dan menghargai nilai-nilai kemanusian. Adapun sebagai suatu proses. Pendidikan multikultural mempunyai tujuan mendorong terciptanya keadilan, kebebasan, toleransi dan kesamaan bagi setiap peserta didik dalam setiap aktivitas yang dilakukan oleh dunia pendidikan. ${ }^{7}$

\section{Sejarah Pendidikan Multikultural}

Pendidikan multikultural lahir sejak 30 silam, yaitu sesudah Perang Dunia II dengan lahirnya banyak negara dan perkembangannya prinsippsinsip demokrasi. ${ }^{8}$ Pandangan multikulturalisme dalam masyarakat Indonesia dalam praktik kenegaraan belum dijalani sebagaimana mestinya. Lambang Bhinheka Tunggal Ika, yang memiliki makna keragamaan dalam kesatuan ternyata yang ditekankan hanyalah kesatuannya dan mengabaikan keragaman budaya dan masyarakat Indonesia. Pada masa Orde Baru menunjukan relasi masyarakat terhadap praktek hidup kenegaraan tersebut. Ternyata masyarakat kita ingin menunjukkan identitasnya sebagai masyarakat bhinheka yang selama Orde Baru telah ditindas dengan berbagai cara demi untuk mencapai kesatuan bangsa. Demikian pula praksis pendidikan sejak

7 James A. Banks and Cherry A. McGee Banks (eds), Multikultural Education: Issues and Perspectives (America: Allyn and Bacon, 1997), hlm. 3-4.

8 H.A.R. Tilaar, Pendidikan, Kebudayaan dan Masyarakat Madani Indonesia, Strategi Reformasi Pendidikan Nasional, Bandung: PT. Remaja Rosdakarya, Yayasan Adikarya IKAPI dan Ford Foundation, 1999, hlm. 16 
kemerdekaan sampai era Orde Baru telah mengabaikan kekayaan kebhinhekaan kebudayaan Indonesia yang sebenarnya merupakan kekuatan dalam suatu kehidupan demokrasi. ${ }^{9}$

Sejak jatuhnya presiden Suharto dari kekuasaannya, yang kemudian diikuti dengan masa yang disebut era Reformasi, Indonesia mengalami disintregasi, krisis moneter, ekonomi, politik dan agama yang mengakibatkan terjadinya krisis kultural di dalam kehidupan bangsa dan negara. Pada era Reformasi pendidikan dijadikan sebagai alat politik untuk melanggengkan kekuasaan yang memonopoli sistem pendidikan untuk kelompok tertentu. Dengan kata lain pendidikan multikultural belum dianggap penting walaupun realitas kultur dan agama sangat beranekaragam. ${ }^{10}$

Era reformasi, membawa angin demokrasi sehingga menghidupkan kembali wacana pendidikan multikultural sebagai kekuatan dari bangsa Indonesia. Dalam era Reformasi ini, tentunya banyak hal yang perlu ditinjau kembali. Salah satunya mengenai kurikulum di sekolah kita dari semua tingkat dan jenis, apakah telah merupakan sarana untuk mengembangkan multikultural. Selain masalah kurikulum juga mengenai otonomisasi pendidikan yang diberikan kepada daerah agar pendidikan merupakan tempat bagi perkembagan kebhinhekaan kebudayaan Indonesia.

${ }^{9} \mathrm{Ibid}, \mathrm{hlm}, 166$

10 Ruslan Ibrahim (2008). Pendidikan Multikultural : Upaya Meminimalisir Konflik dalam Era Pluralitas Agama.Jurnal Pendidikan Islam El-Tarbawi.No. 1.Vol 1. Hal 116 


\section{Aisyah Dana Luwihta}

\section{Tujuan pendidikan Multikultural}

Pada dasarnya tujuan pendidikan multikultural selaras dengan tujuan pendidikan secara umum, yaitu mencetak peserta didik tidak hanya mampu mengembangkan potensi dirinya dalam penguasaan ilmu pengetahuan, seni dan teknologi, melainkan sekaligus mampu mengembangkan dan menerapkan nilai-nilai universl dalam kehidupan.

\section{Pendekatan Pendidikan Multikultural}

Adapun pendekatan dalam pendidikan mutikultural yang dikembang oleh beberapa Negara antara lain: ${ }^{11}$
a. Pendidikan mengenai perbedaan kebudayaan
b. Pendidikan mengenai perbedaan pemahaman kebudayaan
c. Pendidikan bagi pluralism kebudayaan
d. Pendidikan multikultular sebagai pengalaman moral

\section{Nilai-Nilai Multikultural}

Nilai yang diusung dalam konsep pendidikan multikultural ada empat yaitu nilai toleransi, demokrasi, kesetaraan, dan keadilan.

1) Nilai Toleransi (Tasamuh)

Toleransi merupakan kemampuan untuk menghormati sifat dasar, kaykinan, dan perilaku yang dimiliki oelah orang lain. Tasamuh juga dipahami sebagai sifat atau sikap menghargai, membiarkan, atau

${ }^{11}$ Muhiddinur Kamal, Pendidikan Multikultural Bagi Masyarakat Indonsia yang Majemuk, Jurnal AlTa'lim, Jilid 1, Nomor 6 November 2013, Hlm, 456 
membolehkan pendirian (pandangan, pendapat, kepercayaan kebiasaan, kelakuan, dsb) orang lain yang bertentangan dengan pandangan kita.

2) Nilai Demokrasi/kebebasan (al-Hurriyah)

Menurut Kamus Besar Bahasa Indonesia (KBBI), demokrasi diartikan sebagai gagasan atau pandangan hidup mengutamakan persamaan hak dan kewajiban serta perlakuan yang sama bagi semua warga Negara. Dalam pendidikan, demokrasi ditunjukkan dengan pemusatan perhatian serta usaha pada setiap peserta didik dalam keadaan sewajarnya (intelegensi, kesehatan, keadaan sosial, dan seagainya).

3) Nilai Kesetaraan/kesamaan (Al-Sawiyah)

Kesetaraan berasal dari kata setara atau sederajat. Jadi kesetaraan juga dapat disebut kesederajatan. Menurut Kamus Besar Bahasa Indonesia (KBBI), sederajat artinya sama tingkatan (kedudukan, pangkat). Dengan demikian kesetaraan atau kesederajatan menunjukkan adanya tingkatan yang sama, kedudukan yang sama, tidak lebih tinggi atau lebih rendah antara satu sama lain.

4) Nilai Keadilan (al-Adalah)

Istilah keadilan berasal dari kata adl (Bahasa Arab), yang artinya sama atau seimbang. Yang berarti pengakuan dan perlakukan yang sama antara hak dan kewajiban. Jika kita mengakui hak hidup kita, maka 


\section{Aisyah Dana Luwihta}

sebaliknya kita wajib mempertahankan hak hidup dengan bekerja keras tanpa merugikan orang lain. Karena orang lain pun mempunyai hak hidup seperti kita.

\section{METODE PENELITIAN}

Dalam penelitian ini menggunakan pendekatan Diskriptif kualitatif. Dan menggunakan jenis penelitian yang bersifat litere atau kepustakaan (Library Research), yaitu penelitian yang dilaksanakan dengan menggunakan literature sebagai media penelitian, baik berupa kitab, buku, karya ilmiah, catatan maupun laporan hasil penelitian dan penelitian terdahulu. ${ }^{12}$ Buku yang digunakan dalam penelitian ini yaitu buku pendidikan agama Islam dan Budi Pekerti yang dikeluarkan oleh kemendikbud kurikulum 2013.

Proses penelitian dimulai dengan menyusun asumsi dasar dan aturan berfikir, selanjutnya diterapkan secara sistematis dalam pengumpulan dan pengelolahan data untuk memberikan penjelasan dan argumentasi berupa pengumpulan dan penyusunan data, serta analisis dan penafsiran data tersebut untuk menjelaskan pesan teks, karakter teks, makna teks dan hubungan antara beberapa konsep dalam literature tertentu dengan aturan berpikir ilmiah yang diterapkan secara sistematis. Penjelasan ini menekankan pada kekuatan analisis data pada sumber data yang ada, sumber data tersebut diperoleh dari berbagai

12 M. Iqbal Hasan, Pokok-pokok Materi Metodologi Penelitian, (Jakarta: Ghalia Indonesia, 2002), hlm, 11 
buku dan tulisan lain, dengan mengandalkan teori yang ada untuk diinterpratiskan secara jelas dan mendalam.

\section{HASIL PENELITIAN}

1. Muatan Nilai-Nilai Multikultural Yang Dikembangkan Dalam Buku Teks Siswa Mata Pelajaran Pendidikan Agama Islam (PAI) Kelas VII SMP

Nilai-nilai multikultural yang dikembangkan dalam buku teks PAI dan Budi kelas VII SMP menyangkut 4 nilai yaitu nilai toleransi, kesetaraan, demokrasi, dan keadilan. Berikut pembahasan mengenai ke empat nilai multikultural yaitu:

1) Nilai Toleransi

Dalam penelitian yang telah dilakukan, peneliti menemukan nilai toleransi baik dalam muatan materi, kutipan teks, koompetensi, dan panduan guru dalam menyampaikan materi, diantaranya; kompetensi inti (KI) yang pertama dalam mata pelajaran PAI kelas VII, penulis menganggap dari kalimat menghargai dan menghayati ajaran agama yang dianut memiliki nilai toleransi, karena dalam pembelajaran berdasarkan kalimat dalam kompetensi inti tersebut peserta didik tidak hanya diberikan penghayatan ajaran agama yang dianut, namun juga harus mampu menghargai berbagai macam aliran yang dianut atau beberapa aliran yang ada dalam Islam. 


\section{Aisyah Dana Luwihta}

Dalam kalimat yang merupakan KI yang kedua, penulis menganggap memiliki makna nilai toleransi dikarenakan Kompetensi Inti ini pada dasarnya memang diarahkan pada aspek sosial, selain itu adanya kata menghargai dan menghayati yang kemudian diteruskan oleh beberapa kata yang lain yang mengarah pada perilaku terpuji dalam kehidupan bermasyarakat. Dari teks yang telah tertulis tersebut kemudian penulis menganggap Kompetensi Inti kedua ini memiliki nilai toleransi.

Dalam kutipan pada BAB 1 “ kita harus mendengarkan orang lain yang sedang berbicara". Dalam pernyatan tersebut dapat dikatakan mengajarkan peserta didik untuk menanamkan toleransi dimana toleransi dalam hal ini adalah ketika ada orang baik guru atau teman yang lain sedang berbicara dan memerlukan perhatian, peserta didik diharapkan memberikan kesempatan tersebut sebagai bentuk menghargai serta dengan senang hati memperhatikan secara seksama. Itulah toleransi yang dimaksud termuat dalam kutipan teks materi dalam bab I.

Materi tersebut dalam implementasinya disesuaikan dengan dengan KD 4.1 (Menyajikan contoh perilaku yang mencerminkan keteladanan dari sifat Al-Asma'ul al-Husna, Al-Alim, Al-Khabir, As-Sami', Al-Bashir). Kemudian ditunjang dengan panduan guru agar siswa menginterpretasikan materi dalam kehidupan sehari-hari. Maka KD dan panduan dalam buku guru sebagaimana yang berhubungan dengan materi tersebut mengandung 
nilai toleransi jika ketiganya dihubngkan.

Pada BAB IV Meskipun kutipan tersebut tidak secara jelas dituliskan tentang nilai pendidikan multikultural, digambarkan bahwa rasa persatuan yang ditunjukkan melalui suasana yang ada di dalam masjid menjadikan nilai toleransi juga termuat di dalamnya. Toleransi digambarkan setiap individu diharapkan mampu melaksanakan shalat berjamah dengan baik di atas berbagai latar belakang, usia, profesi, dll. Sehingga masing-masing individu harus mempunyai pengakuan akan multikultural.

Dalam silabus dan juga buku guru yang berkaitan dengan pedoman penyampaian materi, dalam KD 3.9 (memahami ketentuan shalat berjamaah) yang menekankan pada penghyatan materi. Hal tersebut secara langsung menjadikan pedoman untuk penghayatan materi tersebut mengandung pula nilai toleransi karena pedoman yang diberikan untuk menunjang materi yang di dalamnya memuat nilai toleransi

Dari kutipan pada BAB XI dapat dipahami banyaknya muatan nilainilai Islam yang ada dalam materi ini, maupun yang dilakukan Rasulullah dalam periode dakwah di Madinah salah satunya berupa nilai toleransi sebagaimana isi dari piagam madinah tersebut. Kompetensi yang diharapkan dalam bab ini adalah KD 2.8 (meneladani perjuangan Nabi Muhammad SAW periode Madinah), serta mengetahui strategi perjuangan Nabi selama di Madinah, pedoman yang diberikan dalam buku guru juga 


\section{Aisyah Dana Luwihta}

mengarahkan pada kompetensi tersebut.

Meneladani artinya mengintegrasikan materi dalam kehidupan artinya jika di dalam materi terdapat banyak nilai pendidikan multikultural dalam buku panduan guru sebagaimana beberapa pedoman menyebutkan dorongan agar siswa meneladani perilaku yang terkait materi yang didalamnya mengandung muatan multikultural. Penulis rasa juga mengandung hal yang sama. Dengan kata lain KD 2.9 dn pedoman penyampaian materi tersebut memiliki hubungan dengan materi yang dalam muatan nilai toleransi

2) Nilai Demokrasi

Dalam penelitian yang telah dilakukan, peneliti menemukan nilai demokrasi baik dalam muatan materi, kutipan teks, kompetensi, dan panduan guru dalam menyampaikan materi, diantaranya;

Pada BAB IX Kutipan tersebut menunjukkan adanya demokrasi yang disampaikan dalam materi tentang kesamaan gender, masing-masing peserta didik memperoleh kompetensi yang sama dalam pembelajaran ini sebagaimana dalam KD 3.10 (memahami ketentuan shalat jum'at). Kompetensi tersebut menjadikan pembelajaran tidak terbatas pada peserta didik putra maupun putri meskipun kewajiban dalam shalat jumat diperuntukkan kepada muslim laki-laki. Selanjutnya pedoman dalam buku guru yang terkait dengan materi shalat jum'at tersebut untuk melakukan 
proses pembelajaran adalah agar peserta didik memiliki pemahaman tentang hal-hal yang terkait dengan pelaksanaan shalat jum'at. Sehingga penulis menganggap dalam KD 3.10 dan panduan yang ada dalam buku guru juga memiliki nilai demokrasi sebagaimana dalam buku materi

3) Nilai Kesetaraan

Dalam penelitian yang telah dilakukan, peneliti menemukan nilai kesetaraan baik dalam muatan materi, kutipan teks, kompetensi, dan panduan guru dalam menyampaikan materi, diantaranya;

Nilai kesetaraan terdapat dalam Q.S Al-Mujadallah ayat 11: Ayat ini dipandang memiliki muatan nilai multikultural adapun sebabnya, dalam ayat tersebut ada kutipan yang menyatakan "niscaya Allah akan meninggikan orang-orang yang beriman di antara kamu dan orang-orang yang diberi pengetahuan beberapa derajat".

Dalam kutipan tersebut sama seperti ayat sebelumya dalam hal memiliki pengakuan adanya kesetaraan dan kesederajatan. Dalam ayat ini manusia memiliki kedudukan yang sama derajat dimata Allah, yaitu dalam kaitannya tentang ilmu, secara tidak langsung nilai kesetaraan terkandung dalam kutipan tersebut jika dilihat dari sudut pandang ilmu pengetahuan. Semua manusia dinyatakan sederajat oleh Allah sebelum masing-masing memperoleh ilmu yang dapat meninggikan derajat mereka. Isi kandungan materi yang memuat nilai kesetaraan tersebut harus dipahami oleh peserta 


\section{Aisyah Dana Luwihta}

didik. sebagaimana dalam KD 3.3 (memahami isi kandungan surah ArRahman ayat 33 dan surat al-Mujadallah ayat 11 serta hadis terkait tentang menuntut ilmu).

Dalam buku panduan guru terdapat panduan yang dimaksudkan agar peserta didik mampu menjelaskan isi kandungan, membaca dengan tartil, mengidentifikasi hukum bacaan, serta hafalan dengan dalil yang terkait. Dari salah satu KD yang telah disebutkan di atas dan panduan yang diberikan adalah memahami isi kandungan dalil yang terkait yang artinya memberikan penjelasan kandungan dalil yang terkait. Menjelaskan isi kandungan dalil merupakan salah satu panduan yang penulis anggap memiliki dorongan memperkuat nilai kesetaraan yang ada dalam buku teks pada bab VI.

Masih terletak pada bab yang sama, mengandung muatan nilai kesetaraan dengan adanya kalimat "kedudukan yang sama dimata Allah". Pemahaman terkait dengan kutipan yang telah disebutkan dalam materi sholat berjamaah tersebut ditekankan dalam KD 3.9 (memahami ketentuan shalat berjamaah).

Selanjutnya, dalam buku guru yang berkaitan dengan kutipan tersebut beberapa poin panduan di bab ini lebih menekankan pada apa yang dapat dilakukan peserta didik setelah proses pembelajaran. Artinya peserta didik mampu melaksanakan shalat berjamaah dan membiasakan 
diri dengan shalat berjamaah. KD 3.9 serta panduan diberikan untuk menunjang materi yang telah disampaikan oleah guru, berkaitan dengan teks materi yang memuat nilai kesetaraan maka buku guru dalam bab IV ini penulis menganggap memiliki nilai serupa dengan buku siswa.

Perilaku empati pada bab VIII terkhusus dalam materi empati. Selain hadits tersebut dalam materi di bab yang sama ini, materi empati yang dituliskan berupa keharusan yang diperintahkan Allah SWT bagi setiap orang muslim sebagai berikut: (1) peka terhadap perasaan orang lain, (2) membayangkan seandainya aku adalah dia, (3) berlatih mengorbankan milik sendiri, (4) membahagiakan orang lain.

Kompetensi yang menyangkut materi yang menunjang materi tersebut adalah KD 3.4 (memahamai makna empati terhadap sesame sesuai dengan Q.S an-Nisa/4:8 dan hadis terkait) dan KD 4.4 (mencontohkan perilaku empati terhadap sesama sesuai dengan Q.S an-Nisa/4:8 dan hadis terkait). Dari KD yang telah disebutkan dapat disimpulkan bahwa setia peserta didik pada akhir pembelajaran mengetahui makna empati dan mampu menerapkan dalam kehidupan sehari-hari.

Dari semua materi yang termuat dalam bab VIII ini pada intinya semua mengajak peserta didik untuk memiliki sikap terpuji dalam kehidupan sehari-hari, materi yang diajarkan mengusung sikap patuh, hormat, kepada guru, serta menghargai sesame dengan asas kesederajatan 


\section{Aisyah Dana Luwihta}

yang terbentuk dalam Empati. Kesederajatan dalam bab ini juga disebutkan oleh sabda Nabi dalam materi, bahwa semua manusia adalah satu kesatuan yang sama besar perannya dalam kehidupan. Panduan tentang materi tersebut berupa dorongan yang dilakukan untuk mencapai kompetensi terkait perilaku terpuji, empati, dan menghormati.

Dengan kata lain pedoman dalam buku pedoman guru terkait kutipan diatas mengandung muatan nilai-nilai multikultural terkhusus nilai kesetaraan karena ada panduan guru untuk memberikan dorongan kepada peserta didik untuk memiliki perilaku terpuji yang didalamnya mengandung nilai kesetaraan.

4) Nilai Keadilan

Dalam penelitian yang telah dilakukan, peneliti menemukan nilai toleransi baik dalam muatan materi, kutipan teks, koompetensi, dan panduan guru dalam menyampaikan materi, diantaranya;

Dalam bab II terkait materi amanah, meskipun tidak diungkap secara langsung, banyak harapan yang dituliskan dalam kutipan tersebut yang mengarah pada perdamaian antar sesama umat manusia yang berdasarkan nilai kesetaraan dan keadilan.

Selain itu ada lagi kutipan dalam bab ini yang dirasa memuat nilainilai multikultural, dalam materi ini amanah terhadap hak orang lain sama halnya dengan menganggap apa yang menjadi hak orang lain adalah milik 
dari orang lain. Maka disini penulis menganggap adanya nilai multikultural dalam materi ini yang tebentuk keadilan secara sederhana.

Selain itu KD yang mengandung materi amanah adalah KD 3.6 (memahami makna amanah sesuai kandungan Q.S al-Anfal/8:27 dan hadis terkait) dan KD 4.6 (mencontohkan perilaku amanah sesuai kandungan Q.S al-Anfal/8:27 dan hadis terkait). Dari KD 3.6 dn KD 4.6 yang telah diebutkan dapat disimpulkan bahwa setiap peserta didik pada akhir pembelajaran mengetahui makna amanah dalam kehidupan sehari-hari.

Selanjutnya buku panduan dalam bab II tersebut juga menyebutkan panduan agar peserta didik berperilaku amanah, dalam materi amanah pada buku siswa ditemukan adanya nilai keadilan yang terdapat pada kutipan terkait amanah terhadap sesama. Dengan demikian penulis menganggap dalam KD 3.6 dan KD 4.6 serta buku panduan guru ini memiliki keadilan sebagaimana dalam buku siswa karena terdapat pedoman mendidik siswa agar berperilaku amanah.

Dalam bab IX materi shalat jumat. Dalam kutipan tersebut sudah sangat jelas mengandung muatan nilai multikultural, dalam kutipan tersebut adalah keadilan dibuktikan dengan tidak adanya pemisah tentang tata cara rukun, dll dalam pelaksanaan shalat jumat, yang menjadi ketentuan pokok adalah muslim laki-laki.

Masih dalam bab yang sama, adanya nilai keadilan yang ditunjukkan 


\section{Aisyah Dana Luwihta}

dengan pemberian materi pelajaran sesuai dengan hak-hak dari masingmasing peserta didik yang juga diungkapkan dalam KD 3.10 (memahami ketentuan shalat jum'at), guru wajib menyampaikan materi sesuai panduan yang telah dituliskan dalam buku guru bagi peserta didik laki-laki yang memiliki kewajiban melaksanakan shalat jumat, maupun pada peserta didik perempuan yang tidak memiliki kewajiban atas shalat jum'at. Hal tersebut menguatkan adanya nilai keadilan yang termuat dalam bab IX tentang shalat jumat.

Sebagaimana dalam pemaparan nilai yang lain, dalam BAB IX kutipan tersebut juga memuat adanya nilai keadilan yang langsung dapat dipetik dari adanya kata keadilan itu sendiri. Pemerintahan yang Rasulullah lakukan dalam periode dakwah di Madinah yang berupa nilai-nilai toleransi, kesetaraan, dan keadilan.

Beberapa pedoman terkait dengan kutipan yang mengandung muatan nilai keadilan tersebut menyebutkan dorongan agar siswa meneladani yang juga diungkapkan dalam KD 2.8 (meneladani perjuangan Nabi Muhammad SAW periode Madinah), perilaku yang terkait materi yang didalamnya mengandung muatan nilai keadilan. Maka penulis menganggap pedoman dalam buku guru untuk materi tentang dakwah Nabi periode Madinah juga mengandung muatan yang sama. Dengan kata lain pedoman yang ada dalam bab ini memiliki hubungan dengan materi 
dalam muatan-muatan nilai keadilan.

Pemaparan diatas telah menunjukkan nilai-nilai multikultural yang dikembangkan dalam buku teks PAI dan Budi Pekerti yang diterbitkan oleh Kemendikbud RI dengan standar kurikulum 2013 mencakup 4 nilai multikultural yaitu nilai toleransi, demokrasi, kesetaraan, dan keadilan. Dalam perumusan standar isi untuk kurikulum 2013 menggunakan 4 aspek yang ingin dicapai yaitu; spiritual, sosial, pengetahuan, dan keterampilan, sehingga dalam konten yang ada dalam satu tahun pembelajaran diharapkan mampu mencakup semua aspek tersebut.

2. Ketepatan Pengembangan Nilai-Nilai Multikultural Dengan Komponen Pengembangan Buku Teks Siswa Mata Pelajaran Pendidikan Agama Islam (PAI)

\section{Kelas VII SMP Berbasis Multikultural}

Pada bagian ini peneliti akan menganalisa mengenai ketepatan nilainilai multikultural yang dikembangkan dalam buku teks siswa mata pelajaran PAI untuk kelas VII SMP mencakup 4 nilai yaitu, 1) Nilai Toleransi, 2) Nilai Demokrasi, 3) Nilai Kesetaraan dan 4) Nilai Keadilan. Nilai-nilai multikultural dikembangkan dalam 13 bab dengan jumlah sub topik keseluruhan 67 pembahasan.

Dari seluruh topik pembahasan yang telah peneliti pilah-pilah dan kelompokkan berdasarkan pertimbangan tertentu, nilai toleransi yang dikembangkan dalam buku teks siswa mata pelajaran PAI untuk kelas VII 


\section{Aisyah Dana Luwihta}

SMP ini hanya terdapat 3 topik merupakan $5 \%$ dari 67 topik pembahasan. Dalam 13 bab yang ada dalam buku teks siswa, nilai toleransi hanya ada 3 bab yaitu BAB 1, BAB 2 dan BAB 4.

Selain nilai toleransi yang dikembangkan dalam buku teks ini, ada juga nilai demokrasi. Nilai demokrasi pada buku teks ini hanya terdapat dalam 1 topik merupakan $2 \%$ dari 67 topik pembahasan secara keseluruhan dan hanya terdapat dalam 1 bab yaitu BAB IX.

Nilai multikultural yang ketiga adalah nilai kesetaraan, nilai kesetaraan yang dikembangkan dalam buku teks ini hanya terdapat dalam 5 topik merupakan $8 \%$ dari 67 topik pembahasan secara keseluruhan. Dari 13 bab yang ada di buku teks tersebut nilai kesetaraan hanya terdapat pada 4 bab yaitu BAB VI, BAB IV, BAB VIII, dan BAB XI. Oleh karena itu tidak semua bab atau topik pembahasan mengandung nilai-nilai multikultural.

Nilai multikultural yang terakhir adalah nilai keadilan. Nilai keadilan dalam buku teks siswa ini hanya terdapat 5 topik merupakan $8 \%$ dari 67 topik pembahasan secara keseluruhan. Dari 13 bab yang ada pada buku teks tidak semua bab mengandung nilai-nilai multikultural. Hanya 3 bab yang mengandung nilai keadilan yaitu BAB II, BAB IX, dan BAB XI.

Berdasarkan prosentase di atas, muatan nilai-nilai multikultural yang dikembangkan dalam buku teks siswa mata pelajaran PAI untuk kelas VII SMP, secara keseluruhan hanya terdapat pada 14 topik dari 67 topik 
pembahasan dalam 13 BAB. Apabila diprosentase nilai-nilai multikultural secara keseluruhan hanya mencapai $21 \%$.

Pada bagian awal sudah dijelaskan bahwa untuk mengukur ketepatan pengembangan nilai-nilai nilai-nilai multikultural dengan pengembangan komponen buku teks siswa mata pelajaran PAI untuk kelas VII SMP menggunakan skala interval dengan 5 klasifikasi yaitu sangat tepat, tepat, cukup tepat, kurang tepat, dan tidak tepat dengan prosentase masing-masing.

Sesuai dengan skala yang digunakan peniliti utuk mengukur ketepatan buku teks dikatakan tepat apabila mencapai $61 \%-80 \%$. Sedangkan nilai-nilai multikultural dalam buku teks ini hanya mencapai 21\%. Apabila diukur dengan skala interval muatan nilai-nilai multikultural dalam buku teks siswa ini termasuk dalam klasifikasi kurang tepat. Karena prosentase yang diperoleh secara keseluruhan belum mencapai target yaitu 61-80\%. Jadi dapat disimpulkan bahwa ketepatan pengembangan nilai-nilai multikultural dengan komponen buku teks siswa mata pelajaran PAI kelas VII SMP dikatakan kurang tepat.

\section{DAFTAR PUSTAKA}

A. Banks, James \& Cherry A. McGee, Multicultural Education: Issues and Perspectives (Boston: Allyn and Bacon, 1989)

(eds), Multikultural Education: Issues and Perspectives (America: Allyn and Bacon, 1997) 


\section{Aisyah Dana Luwihta}

Hasan, M. Iqbal, Pokok-pokok Materi Metodologi Penelitian, (Jakarta: Ghalia Indonesia, 2002)

Ibrahim, Ruslan, (2008). Pendidikan Multikultural : Upaya Meminimalisir Konflik dalam Era Pluralitas Agama.Jurnal Pendidikan Islam El-Tarbawi.No. 1.Vol 1.

Kamal, Muhiddinur, Pendidikan Multikultural Bagi Masyarakat Indonsia yang Majemuk, Jurnal Al-Ta'lim, Jilid 1, Nomor 6 November 2013

Peraturan Pemerintah No. 19/2005 pasal 43

Suhadi, dkk, Politik Pendidikan Agama kurikulum 2013 dan Ruang Publik sekolah, CRCS, Sekolah Pascasarjana, UGM, 2014

Tilaar, H.A.R., Pendidikan, Kebudayaan dan Masyarakat Madani Indonesia, Strategi Reformasi Pendidikan Nasional, Bandung: PT. Remaja Rosdakarya, Yayasan Adikarya IKAPI dan Ford Foundation, 1999

Widyastono, Herry, Pengembangan Kurikulum di Era Otonomi Daerah, (Jakarta:

Bumi Aksara, 2014) 